\title{
DOUBLE DIFFERENT PATHOLOGY AT SAME SITE- CARCINOMA SCROTUM AND ATYPICAL MYCOBACTERIA IN SCROTUM
}

\author{
M. Madan ${ }^{1}$, Nischal. K², Mahesh. M. S3, Srikanth.T4.
}

\section{HOW TO CITE THIS ARTICLE:}

M. Madan, Nischal. K, Mahesh. M.S, Srikanth.T. "Double different pathology at same site- carcinoma scrotum and atypical mycobacteria in scrotum". Journal of Evolution of Medical and Dental Sciences 2013; Vol2, Issue 27, July 8; Page: 4983-4987.

ABSTRACT: Scrotal cancer is an epidermoid malignancy of the scrotum, characterized initially by a small sore that may ulcerate. We report a case presented with discharging ulcer at the root of scrotum encroaching root of penis and diagnosed to be squamous cell carcinoma. Patient underwent total peno-scrotectomy with bilateral orchidectomy with perennial urethroplasty. Simultaneously patient was found to be harboring atypical mycobacteria over scrotum.

INTRODUCTION: Scrotal carcinoma is uncommon with over all incidence of 0.1/100000 cases per year with majority being squamous cell carcinoma [1]. It was the first malignancy shown to be caused by an environmental carcinogen.

CASE REPORT: A male patient aged about 50 years from Kolar, came with chief complaints of discharging ulcer at the root of scrotum since one year associated with fever since one week. Recent history suggests no bowel or bladder disturbances

LOCAL EXAMINATION: ulcero proliferative growth of size 10x6 cm, irregular in shape foul smelling discharge involving the right hemi scrotum [FIGURE 1]. Testis seen in the floor of the ulcer Swab from scrotal lesion for culture showed Atypical mycobacteria on Z-N stain, thought to be contaminant initially and other organism isolated was Pseudomonas. Biopsy of scrotal mass done on 18-04-2009 showed moderately differentiated squamous cell carcinoma scrotum

SURGERY: Peno- scrotectomy and bilateral orchidectomy with perennial urethrostomy [FIGURE 2 AND FIGURE 3]

Histopathology specimen showed - [FIGURE 4] moderately differentiated squamous cell carcinoma with large areas of ulceration and necrosis. Tumour is infiltrating penis and urethra. Section studied from right, left, superior, inferior and deep surgical margins are free from tumour.

There was sloughing at the post op wound and gaping was present on $5^{\text {th }}$ post op day. So radiotherapy was deferred to a later date. From the wound site culture swab was taken which showed Pseudomonas and Enterobacter. No AFB was isolated in second culture. At a later date plastic surgeon opinion was sought regarding closure of post op raw area and $v-y$ plasty was done on 25-06-09.

On $4^{\text {th }}$ post op day patient had small crust at the $\mathrm{v}-\mathrm{y}$ plasty site and it was sent for culture. Culture came positive for Atypical mycobacteria and now it was confirmed as pathogen not the contaminant. Staples were removed on $9^{\text {th }}$ post op day. Wound was clean, no discharge present.

Patient recovered well

Radiotherapist opinion was sought they opined to start radiotherapy after 15 days and patient was discharged. 
DISCUSSION: The scrotum is a seven layer pouch which invests the testis, testicular adnexa and distal spermatic cord. The scrotal lymphatics drain into the corresponding superficial inguinal lymph nodes. Tumour has been reported that arise out of virtually any of components of scrotal wall $[2]$.

Squamous cell carcinoma is exceedingly rare. It was the first malignancy linked to occupational exposure [3]. Men with squamous cell carcinoma usually present during $5^{\text {th }}$ to $6^{\text {th }}$ decade of life. Scrotal lesion is usually not of subtle lesion as patients often come after several months because of embarrassment. The early lesion is a slow growing pimple, wart or nodule and most patients suffer for 8-12 months before seeking medical assistance and diagnosis [4] as in this case.

The staging system for scrotal cell carcinoma is as follows:

Stage A1- Localised to scrotal wall

Stage A2- Locally extensive tumours invading adjacent structures

Stage B -Metastatic disease involving inguinal lymph nodes only

Stage C- Metastatic disease involving pelvic lymph nodes only

Stage D- Metastatic disease involving beyond lymph nodes

Patients with stage A have approximately $75 \%$ or better chance for long term survival [5]. However in stage $C$ and D disease the long term survival is poor [6].

Prognosis correlates with extent of nodal involvement with virtually no survivors if iliac nodes are involved. Ability to achieve a negative margin at the time initial surgery is an important prognostic factor [7].

The treatment of choice for primary scrotal Squamous cell carcinoma is wide local excision with resection of skin and underlying dartos muscle in the region [8].

Adjuvant radiotherapy and chemotherapy in form of four courses are recommended to achieve a better disease free survival. Thus Squamous cell carcinoma is a rare condition that treated by multi disciplinary approach.

CONCLUSION: A patient to have two different pathologies at same site I e Ca scrotum and atypical mycobacteria of scrotum simultaneously is very rare. Atypical mycobacteria can hinder the wound healing as it has happened in this case.

We believe this case will raise the awareness in our environment of existence of this disease ie, Ca Scrotum proper and also raise awareness about the effect of atypical mycobacteria on wound healing and improve the index of suspicion among practicing surgeons and oncologist about the existence of two completely different pathologies at same site simultaneously.

\section{REFERENCES:-}

1. Vandeweyer E, Deraemaecker R (2000) Basal cell carcinoma of scrotum: J urol.163:914

2. Rowland RG, Herman JR(2002) Tumours and infectious diseases of the testis, epididymis and scrotum : Adult and paediatric urology, Philadelphia: Lippincott, Williams and Wilkins

3. Waldron HA (1983) A brief history of scrotal cancer. Br J Ind Med 40:390-401.

4. Presti JC Jr (2008) Genital tumours. Smith's General urology. New York: Mc Graw hill 375-87.

5. Chatora G, Rourke T, Sezhian N (2007). A case of inguinal lymph node metastasis treated by multi disciplinary approach: Journal of urology 4:1-8. 


\section{CASE REPORT}

6. Lowe F.C (1992) Squamous cell carcinoma of the scrotum: Urologic clinics of north America 19(2):397-405

7. Ray B, Whitmore WF Jr (1997) Experience with Carcinoma of the scrotum. J Urol 117: 741-5

8. Jingbo Zhang, Manmeen Kaur: Genito urinary Case report 11: New York University School of Medicine Department Of Radiology. March 22, 2004.

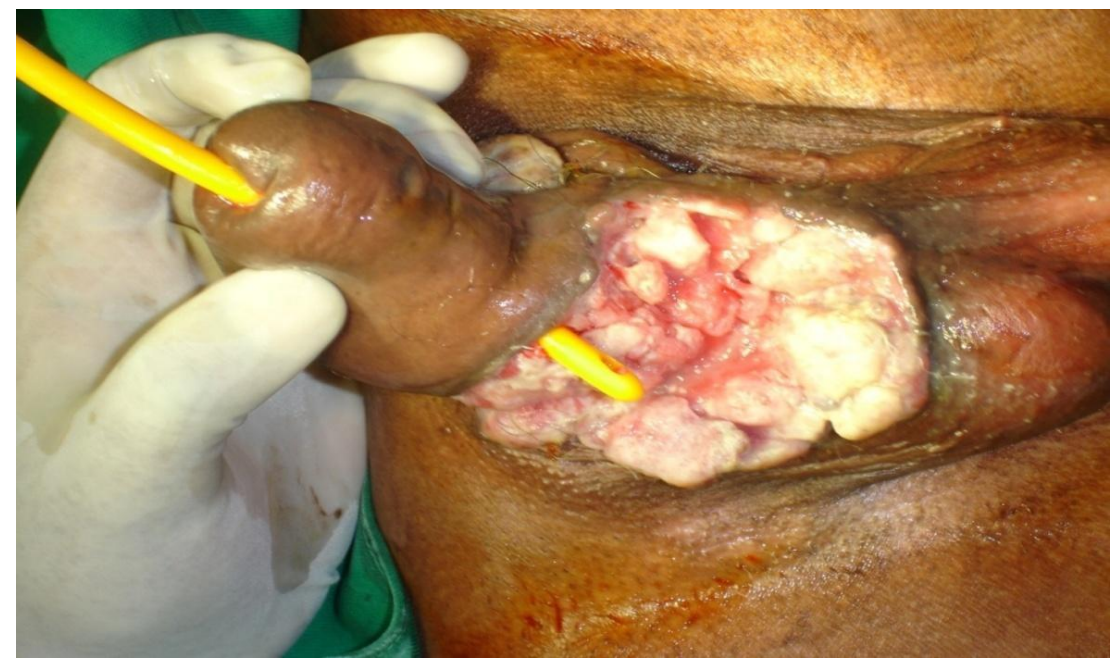

FIGURE 1: CARCINOMA SHOWING INVOLVEMENT OF PENIS AND URETHRA

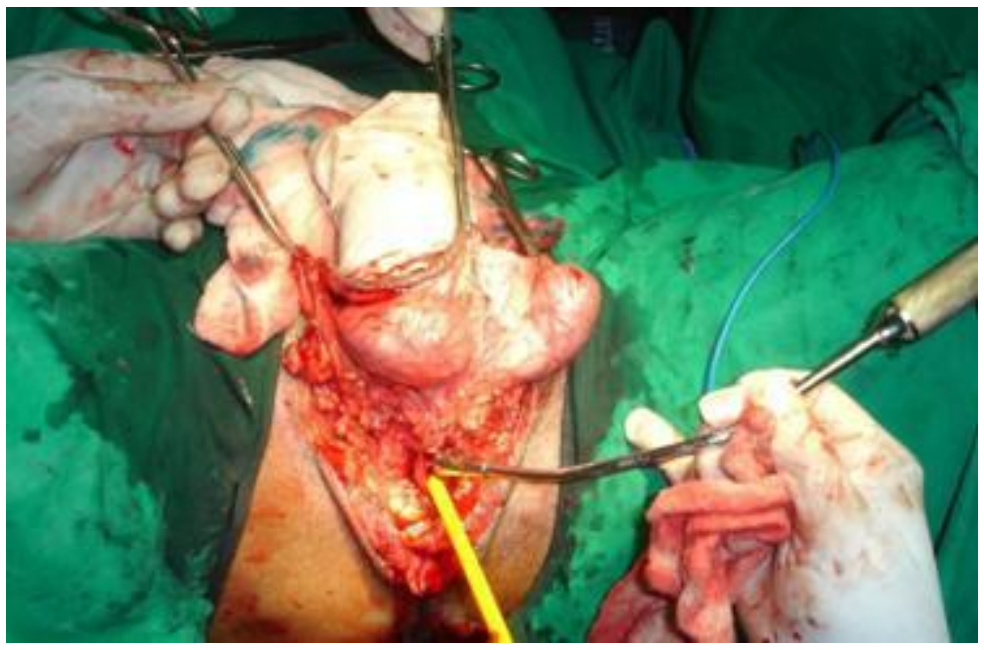

FIGURE 2: SHOWS SCROTUM TESTIS PENIS TO BE EXCISED 


\section{CASE REPORT}

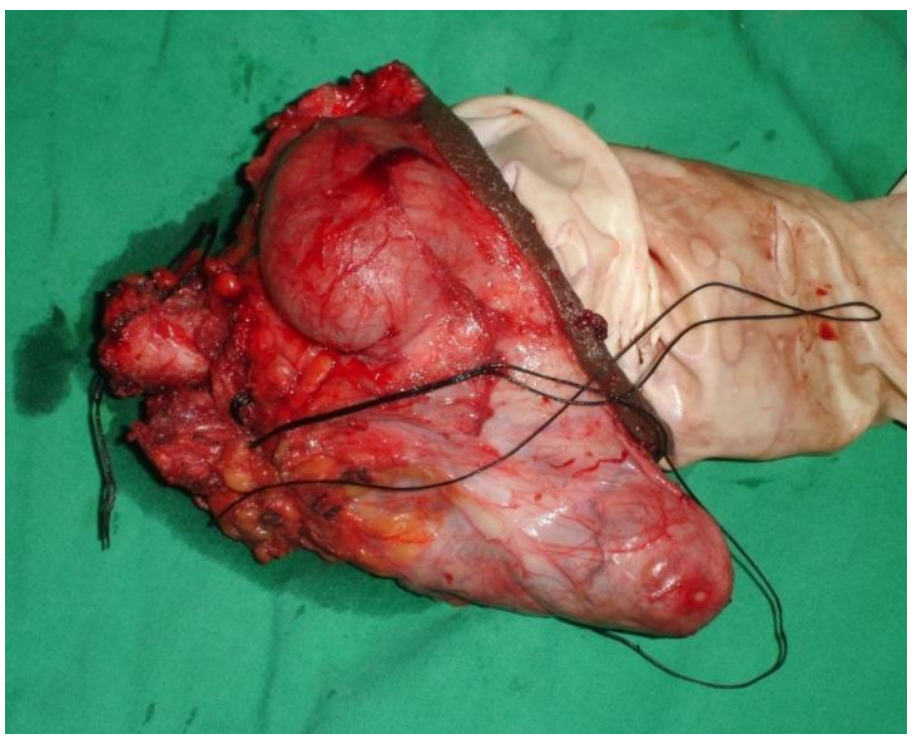

FIGURE 3: SHOWS EXCISED SPECIMEN

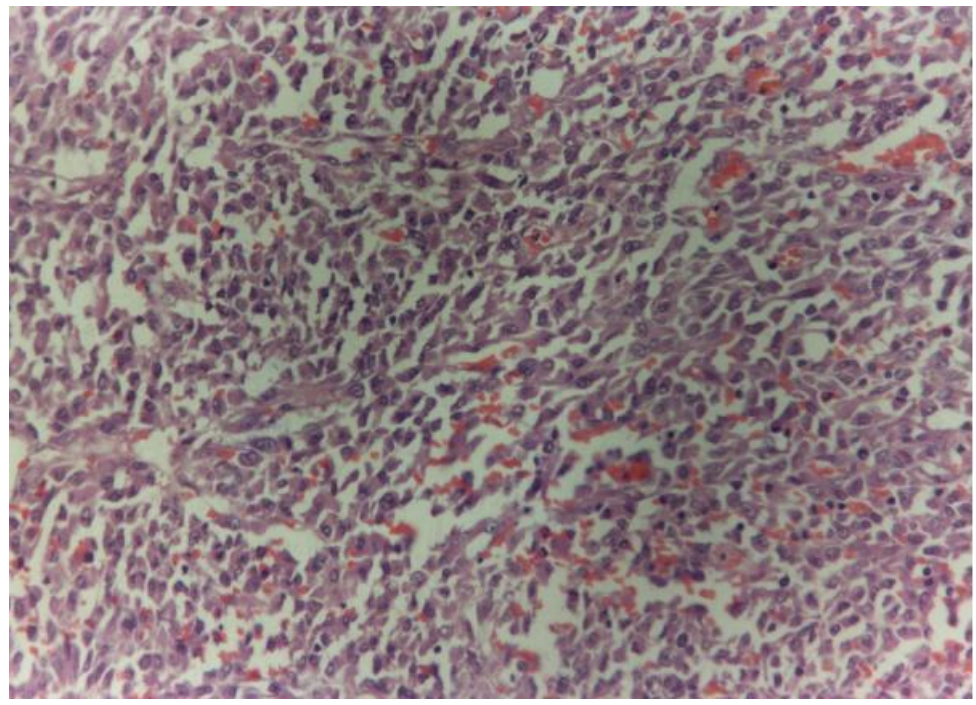

FIGURE 4: WELL DIFFERENTIATED SQUAMOUS CELL CARCINOMA 


\section{AUTHORS:}

1. M. Madan

2. Nischal. K

3. Mahesh.M. S

4. Srikanta. $\mathrm{T}$

\section{PARTICULARS OF CONTRIBUTORS:}

1. Professor \& Head of the Department, Department of Surgery, Sri Devaraja Urs Medical College, Tamaka, Kolar.

2. Associate Professor, Department of Surgery, Sri Devaraja Urs Medical College, Tamaka, Kolar.

3. Assistant Professor, Department of Surgery, Sri Devaraja Urs Medical College, Tamaka, Kolar.

4. Post Graduate, Department of Surgery, Sri Devaraja Urs Medical College, Tamaka, Kolar.
NAME ADRRESS EMAIL ID OF THE CORRESPONDING AUTHOR:

K. Nischal,

Associate Professor,

Department of General Surgery, Sri Devaraja Urs Medical College,

Tamaka, Kolar.

Email-knischal697@gmail.com

Date of Submission: 28/06/2013.

Date of Peer Review: 28/06/2013.

Date of Acceptance: 05/07/2013.

Date of Publishing: 08/07/2013 